\title{
A COMPARATIVE TYPOLOGICAL ANALYSIS OF THE JEWISH APOCALYPTIC FEATURES AND ZIMBABWEAN APOCALYPTIC MUSIC: A REFLECTION ON HOSIAH CHIPANGA'S MUSIC
}

\author{
Bishow Samhika \\ University of Nairobi
}

\begin{abstract}
Zimbabwean apocalyptic literature (songs of liberation) was produced during the colonial and post-colonial era to critique oppressive measures. Apocalyptic literature evinces itself in the following characteristics: symbolism, dualism, pseudonymity, eschatology, revelation, vaticinium ex eventu and exhortations. Zimbabwean apocalyptic music, like Jewish apocalyptic literature was developed to answer the difficulties associated with the justice of God in the light of suffering under repressive leadership. In the Jewish context, the genre developed during the post-exilic period. In the context of this article, songs of liberation in Zimbabwe form this type of apocalyptic literature. One would assume that there was a direct influence of Jewish apocalypticism on Zimbabwean apocalyptic music. However, it is undeniable that Jewish apocalyptic ideology or features are very prominent in Zimbabwean liberation music. Although apocalyptic music in Zimbabwe is attributed to musicians like Thomas Mapfumo, Oliver Mtukudzi, Leonard Zhakata, Zex Manatsa and Paul Madzore, this article focuses on Chipanga's apocalyptic music, which exhibits features similar to those found in biblical apocalypticism.
\end{abstract}

Keywords: Apocalypticism; Esoteric; Phenomenon; Sitz-im-leben and music

\section{Introduction}

An analysis of Jewish apocalyptic literature shows that the genre developed during times of suffering and extreme deprivation. The literature unfolded in a coded or hidden language. In this way, the author communicated his circumstances without being detected by the oppressors. Thus, Jewish apocalyptic literary tendencies are similar to Chipanga's apocalyptic songs. Like the message from Jewish apocalyptic literature that was always hidden, Chipanga's songs are characterised by idioms, proverbs, euphemism, metaphors and parables that need decoding. Biblical figures, ancestors, and animals play a significant role in Chipanga's songs as codes for his message. Hence, the article investigates the similarities between Jewish apocalyptic features and Hosiah Chipanga's apocalyptic music.

The comparative typological analysis is helpful in testing this hypothesis, as it assists in comparing elements that are functionally similar. Although Jewish apocalyptic literature and Zimbabwean apocalyptic music have no common origins or context, they have the comparative functions when they manifest in each particular community. The main reason is that manifestation of Jewish apocalypticism demonstrates that human 
beings have a tendency to respond in similar ways when confronted by similar challenges though they exist in a historical and geographical gap. The comparative typological analysis may also help in analysing the roots of Chipanga's apocalyptic music in Zimbabwe. The observation is that apocalyptic music was born from unfulfilled promises. During the liberation struggle, Zimbabweans were promised a good life by the freedom fighters. On top of the list was improved quality of life, free education, economic empowerment, employment, free transport, peace and prosperity, to mention a few.

After independence, the situation remained the same, and oppressive systems continued to be rehabilitated. Thus, for Zimbabweans to maintain their morale or hope the same way they did during the struggle, they developed apocalyptic music. Apocalyptic music, like Jewish apocalyptic literature, kept people aware of their obligation to resist oppression but with caution to avoid victimization. Like Jewish apocalyptic literature, the social aspect of apocalyptic music becomes a tool of power to mobilise people. Hence, the comparative typological theory may help in comparing what motivated Chipanga to express his lyrics in coded language just like Jewish apocalyptic seers or prophets.

\section{Background of Jewish apocalypticism and its characteristic features}

Apocalypticism is an ideology developed within post-exilic Jewish society and reflected in Daniel, Third Isaiah ${ }^{1}$ and other non-canonical books such as Enoch, Ezra, and Baruch. Apocalypticism, as a literary genre is prevalent in the book of Daniel in the Old Testament and Revelation in the New Testament. The definition of apocalypticism portrays a genre which is esoteric and uniform, yet by nature, is not a homogenous phenomenon. Its characteristic features, in most cases, get transformed (Dunn 1977:310315). The features are classified as primary and secondary. The primary features are those which show a close affinity with Zoroastrianism, whereas the secondary features have their Sitz-im-leben within the Jewish religious pillars like wisdom and prophecy. Hence, features like revelation, pseudonymity, symbolism, dualism, eschatology, vaticinium ex event, exhortations and numerology characterize the phenomenon.

Revelation as a characteristic feature of apocalypticism is mediated through dreams and visions whereby the seer gets a glance of the secrets of God's world and the future (Lawrence 2005). An analysis of apocalypses of Daniel, 2 Esdras and Revelation reflect this feature. Daniel envisions the imminent destruction of Antiochus IV Epiphanes and the conferral of the kingdom of God on the saints of the most high. The angel in 4 Ezra explains that the vision of the transformation of the woman from mourning and weeping to glory signifies the transformation that would happen to Zion. Hence, to Bauckham (2008:45), Daniel's activity in Daniel 2, 4, and 5 consisting interpretations of the dreams of Nebuchadnezzar and the mysterious message on Belshazzar's palace wall reflects the function of the disclosure of the future.

Pseudonymity is another characteristic feature of Jewish apocalypticism. Pseudonymity derived from the Greek word pseudonym translates as a false name, but

Third Isaiah refers to the third division of the book of Isaiah that covers Chapters 56-66. Though unknown the author of these chapters is viewed to have penned them after the Babylonian exile. Most of Isaiah 56-66 reflects a background of intense suffering believed to have prevailed between the time Sheshbazzar attempted to rebuild the Temple and to its completion under Zerubbabel in 515 B.C. (Gregory 2007:475-496). 
Jewish Apocalyptic Features \& Zimbabwean Apocalyptic Music: Reflection on Hosiah Chipanga Music 3

in an apocalyptic setting, it refers to a state of the disguised name. Mazzafferi (1989:181) concludes that apocalyptic contenders use the device of pseudonymity by which they regularly attach themselves to prominent figures in history. Murphy (1996) agrees with Mazzafferi in his assertion that all Jewish apocalypses are pseudonymous. From such an understanding, it is observed that Jewish apocalypticists attach themselves to Jewish antiquity heroic figures like Adam, Enoch, and Abraham, sons of Israel, Moses, Joshua, Ezra and Baruch. Thus, according to Buttrick (1989), Daniel 7-12 is a pseudonymous text written during the Maccabean period by an unknown person who in turn attributed his work to Daniel. Hartman (1978) agrees with Buttrick that the unknown authors of Daniel 7-12 identify themselves with the sixth century BC (Dan. 1-6).

Murphy also points out that at least five apocalypses preserved in the Ethiopic Aramaic fragments from Qumran are assigned to Enoch who is believed to have walked with God (Gen. 5:24). Enoch is taken as a heroic figure after enigmatically being taken by God. Hence, he is considered an appropriate figure for heavenly revelations. An explicit assumption about the use of heroic figures possibly was made to increase authority and acceptance of the texts. It should be noted that pseudonymity was not an invention by authors. However, it appeared to be the prevalent tradition as most of the Old Testament texts are either anonymous or pseudonymous. Some Old Testament examples of anonymous writings include the Tetrarch, Deuteronomistic History, Proverbs, Psalms, Job, Deutero-Zechariah (9-14) and Wisdom of Solomon, among others. From a historical perspective of the second century, pseudonymity was used to conceal one's identity to the oppressive systems. Since heroic names were for wellknown persons, they would foster unity and identity among the oppressed community. Collins (2003) supports this notion in his conclusion that attributing work to an ancient author removes the work from its current setting and places it in another context which would serve to validate the view of defectiveness of the present world and the need to seek revelation.

Jewish apocalypticism also employs elaborate symbolism. It is heavily characterized by the use of symbols and images which include images, animals, and signs of the sun, stars, moon and numbers. According to Kummel (1990:23), symbols and images carry with them a multiplicity of interpretations and usually distortions are common. For instance, we observe that animals and birds are used in Ezekiel 17 (the two eagles), 2 Esdras 11 (the eagle vision) and 2 Baruch 29 (Behemoth and Levithan). The symbols are also presented in numerical puzzles. For instance, number seven in Daniel 9:24 and Revelation as well as the number forty-nine in the book of Jubilees. It is acknowledged that symbolism is a significant characteristic of apocalyptic literature, and meaning was to be interpreted out of these symbols. The symbols vary, and include number symbols, colour symbols, animal symbols, amongst others. These act as the vehicles and agencies of secret wisdom. Partly, the usage is traditional as some of it is derived from oriental mythology, and some from earlier prophecy.

A good example is found in Daniel which mentions the four beasts, the fourth of which had ten horns, among which appeared a little horn. The timbre and tonality of Daniel reflect some changes in Daniel 7 with a dream that Daniel has of four great beasts emerging from the sea. In Daniel 8, he has a vision of a ram that conquered the whole world until a he-goat from the west charges at it with the full force of its fury and breaks its horns (Dan. 8:5-7). These animals represent empires, and the little horn represents 
Antiochus Epiphanes. The kings of Media and Persia are later represented by a ram, while a he-goat stands for Greece. This kind of imagery is familiar to us also in the Book of Revelation. Animals refer to a variety of things. Beasts refer to the power of Satan, and the lamb represents the sacrificial animal, Jesus Christ. Lions imply kings and eagles or oxen are superior animals of their kind, and their horns represent power, whilst multiple heads impersonate rulers.

Dualism is another feature which is prevalent in Jewish apocalypticism. Within the Jewish apocalypticism, dualism refers to an idea of the prevalence of opposing forces in the universe. According to Collins (1998:24), an act of dualism within apocalypticism follows the doctrine that reality consists of two essential opposing elements. In his analysis of the Book of Revelation, Sanders (1972:134) adds that apocalyptic literature also tends to recognise the existence of worlds regarding ages to which the end of one will mark the beginning of the other. This is even further signified by the concept of the coming of the 'new house,' that represents, Jerusalem. This 'new house' is referred to as the New Jerusalem which would come to replace the old corrupted one that existed before.

Dualism may be viewed in three forms, namely ethical, spatial and temporary. However, it looks at events from two different perspectives. From these perspectives, most Jewish apocalypses reveal the reaction of the heavens to evil on earth from which contrast is made between the present evil age and the future virtuous age. In his endeavour to put the Enochic apocalyptic texts into Israelite religious context, Nickelsburg (2003:44) observes that the Enochic authors locate human existence at the intersection of a set of dualisms. Nickelsburg (2003) concludes that to the Enochic authors, the earth is not heaven, neither the present age nor the age to come. Thus, 1 Enoch makes an excellent example of spatial dualism that exists between the earth and heaven or the recesses of the inaccessible to humanity. Again, 1 Enoch highlights a temporal dualism that exists between the present and the eschatological future (Lawrence 2005). From Enoch chapters 6-11, dualism is further enhanced, primarily, through dualistic myths about how evil originated. The ethical dualistic view also emerges whereby people are divided into two classes of moral conduct, the righteous and the wicked. Within the ethical dualism is the conviction that each human being can belong only to one side or the other, and this is characterised by the continued existence of good and evil deeds. Additionally, in Daniel, dualism is presented in the light of how Judaism was viewed as being opposed to Hellenism under Antiochus IV Epiphanes. Therefore, dualism as a characteristic feature of apocalypticism presupposes that there is ever a crisis or constant conflict.

Another central core of apocalyptic belief is a futuristic eschatology in which the future is envisaged through direct divine intervention. This will be equal to a universal judgment of the nations and a new age of salvation. From such a conception, the world will be radically transformed in the future. For example, Daniel's prayer and Gabriel's revelation in Daniel create the impression that the future is seen as being predetermined by Yahweh although, this is not the case. The reason is that the 'future' is described in terms of the already passed history. The only reference to 'future' is found in the last few verses where a prediction is made. This is reflected within chapters where a correction is also needed when the prediction is not realised (Lucas 2002:224). Prophecy shaped the form of history so that it seems to be predetermined. The purpose is to give readers 
Jewish Apocalyptic Features \& Zimbabwean Apocalyptic Music: Reflection on Hosiah Chipanga Music 5

and listeners the idea that the description of the narrator regarding the prediction of the future can be trusted (Helberg 1994:93). Thus, the term 'end times' points to the end of Jewish exile, and it is interpreted here in relation to the end of Antiochian suppression and persecution.

Another issue that is related to eschatology is vaticinium ex eventu, a Latin phrase translated as 'prophecy from the event' or 'prophecy after the event' (Milinovich 2011). The analysis of apocalypses of Daniel, Enoch and 4 Ezra reflect this feature. For instance, the redactor of Daniel's apocalypse is writing in the second century from its fictional timeframe of the sixth century BC. In the light of the persecution of the Jews by Antiochus Epiphanes, Daniel writes as though this is during the diaspora in Babylon. In other words, Daniel presents history as if it was a prediction of the future. Another example is Daniel 12 that presupposes the vaticinium ex eventu of Daniel 11:2-39. Enoch also, in the animal apocalypse which was set in the Maccabean revolt, is written as if the Sitz-im-Leben is from the beginning of the days. In his presentation of the destruction of Jerusalem, 4 Ezra (100CE) depicts the writing as if it was the work of Ezra, the scribe round about $556 \mathrm{BC}$. Although the technique characterised Jewish apocalypticism, it was prevalent in other biblical literature. Scholars critique this technique as a form of deception, but Hartman (1978) argues that the writers of apocalypse used the technique to give their work credibility and authority. Vries (1995) supports this assertion in his conclusion that all passages with this form of transition are correct predictions. According to Vries (1995:72), the redactors of literature characterized by vaticinium ex eventu were projecting the future through intuitive inspiration, not from already known facts. Therefore it should be acknowledged that ex eventu was used to strengthen the patience and courage of the devout who were suffering persecution. Presentation of the events in this way would instil new hope as they remember how God helped others in the past, which offers an alternative picture of reality.

Exhortation is another Jewish apocalyptic feature. The Epistle of Enoch is replete with exhortations in the form of education by the patriarchs. The exhortations also include woes and warnings against acts of unrighteousness. Horsley (2012:289) affirms that moral exhortations have always been one of the functions of apocalyptic literature. In other words, apocalypse comprises of exhortations of high ethical standard in which there is a constant call for adherents to improve their relationship with the deity.

Additionally, numerology is another characteristic feature of apocalypticism. Both Daniel and Revelation use numbers to depict events and historical figures. Hence, the manifestation of apocalypse in Zimbabwe and Chipanga's music reflect the same functionality of the features which were prevalent in Jewish apocalypticism.

\section{Hosiah Chipanga, the messenger of God}

The musical career of Hosiah Chipanga as an apocalyptic 'seer' follows the path of Thomas Mapfumo. He started his career from the periphery, then at some point moved to the centre, but eventually trekked back to the periphery. Chipanga rose to prominence sometime after Thomas Mapfumo who was already in the music industry. Hosiah Chipanga is a typical apocalyptic musician whose messages decry the evils of the ruling elite. While in some songs, Chipanga adopts Thomas Mapfumo's bluntness, in most songs, Chipanga conceals his message in parables, euphemisms and metaphors. 
Chipanga uses imagery from the Bible and African traditional setting quite frequently. His background is responsible for this approach. Hosiah Chipanga was born on 21 February in 1952 in a Marange Apostolic Church family, in the Marange communal area. He thus grew up as a member of the Marange Apostolic Church. ${ }^{2}$ Chipanga believes that he received a call from God to be a prophet or His messenger at Shebba Mountain, Penhalonga in 1977. These two components influence his worldview and approach to life in general. Since he was born in a rural area, he has a simplistic view of life and its expectations. Chipanga's songs also reflect the influence of the apostolic churches (churches that have a negative view of the city and extravagant wealth). Chipanga started his musical career in 1982, at the height of the euphoria of independence. At that time, Thomas Mapfumo was still celebrating the ruling party and independence of Zimbabwe.

Nationalist politics influenced Chipanga to a great extent. His wishes, as expressed in songs, are those that were promised during the war of liberation by the fighters. The fighters promised free houses, well-paying jobs, free education, free health-care and free service delivery. In a way, the fighters promised heaven on earth, a society that is egalitarian and characterised by social justice. Given his background, the message must have resonated with Chipanga to such an extent that he almost always sang about the possibility of that utopian world. Like a Jewish apocalyptic seer, Chipanga looks forward to its establishment on earth. Since 1982, Chipanga has been leading his musical group, which initially was called the Broadway Sounds. However, in 2007, the name of the group was changed to Vaparidzi veShoko, ${ }^{3}$ that is, Preachers of the Word. Chipanga changed the name of the band to relate it to the mission that he claims God gave him, which is to preach to people to be converted and serve God. However, Chipanga is regarded as a controversial figure due to three factors.

First, Chipanga sings sungura ${ }^{4}$ music, a genre, which, according to Zimbabwean standards, is secular, yet he is a Christian and "mupostori" (an Apostle). Secondly, Chipanga sings about socio-economic and political issues more than what Zimbabweans would consider conventional gospel messages. Thirdly, because of his grounding in an African worldview, some claim that he is a 'spirit medium', for he claims to receive messages from the dead through dreams and visions. This is a claim that Christians in Zimbabwe believe is not compatible with Christianity. Chipanga however, believes that all these practices are not contradictory (Masau 2013). They cross-pollinate his ideas about human existence.

\section{Characteristic features of Jewish apocalypticism in Chipanga's music}

An analysis of Chipanga's music reflects key features of Jewish apocalypticism. As alluded to earlier, there is no claim of a direct influence of Jewish apocalypticism on Zimbabwean apocalyptic music. However, a comparative typological approach helps to unpack the areas of common functionality. Chipanga employs revelation in his

\footnotetext{
Marange Apostolic Church is one of the Pentecostal churches in Zimbabwe and mostly prominent in the eastern part of Zimbabwe

3 Vaparadzi veShoko is a Shona term which is translated "Preachers of the Gospel.

4 Sungura is a local Zimbabwean music genre. The music became popular in the 1980s soon after the independence. It was pioneered by Ephraim Joe and his Sungura Boys.
} 
Jewish Apocalyptic Features \& Zimbabwean Apocalyptic Music: Reflection on Hosiah Chipanga Music 7 apocalyptic songs. Due to his grounding in an African worldview, some people claim that he is a 'spirit medium', for he claims to receive messages from the dead through dreams and visions (Masau 2013). The fact that Christians describe Chipanga as a 'spirit medium', however, confirms that Chipanga receives messages through dreams and vision. Thus, we observe the feature of revelation, which is signified by dreams and revelations. In most of his songs, Chipanga wishes for speedy intervention by God in creating a new world order. Hence, he is seen as communicating with God and the dead from whom his dreams and visions are generated. Chipanga is fond of mentioning Zimbabwean ancestors, heroes (Mbuya Nehanda, Kaguvi, Chaminuka, Chitepo, Nkomo, and others) and biblical characters, (God, Abraham, Moses, Jesus, Pharaoh and Satan). In his song Hove dzemugungwa (Fish from the sea), he makes an analogy between the rich and poor as presented in a parable in Luke 16:19-3.

Furthermore, Chipanga employs pseudonymity in his music. Like Jewish apocalyptic seers, Chipanga's concealing of names saves him from victimisation and, in that way, he manages to express his political and social opinions. For instance, he uses Mbuya Nehanda as a pseudonymous name for the early Zimbabwean spirit medium, but that is not the real name of the medium spirit. From the pseudonymity, we see some parallels again between Jewish apocalyptic and Chipanga's apocalyptic music. As in Jewish apocalypticism, once the battle lines are drawn, the pseudonymity of the seer is blown away. During the Jewish apocalyptic era, pseudonymous writers no longer hid their identity but preached the message of hope publicly. They did not flee from pain or devastating realities but engage them head-on. The same is witnessed in Chipanga's music, as he later began to speak openly (Smith 2011:4).

A similar trend is observed in his song Ivhu redu nderipi? (Which of these is our land?) (2004), for instance. In this song, Chipanga deployed this strategy to proclaim his message (Chitofiri 2017) that focused on the pertinent issue of land redistribution in postindependence Zimbabwe. To avoid the wrath of the ruling government for his criticism of their programme, Chipanga addressed questions about the land reform to well known long-dead ancestors and heroes of the First and Second Chimurenga such as Mbuya Nehanda, Sekuru Kaguvi, Mufemberi Chaminuka, Tongogara, Ziyapapa Moyo and Joshua Nkomo. Like Jewish apocalypticists, he resorted to pseudonymity to embellish his message. By referring to the heroes who were known to have played a significant role during the liberation Chipanga not only saved himself from victimisation, but united the people of Zimbabwe. Chipanga also addressed the pertinent questions to the living, those who participated in the land reform. However, he did not mention their real names but addressed them as the chimbwido (female war collaborator), mujibha (male war collaborator) and Comrade (war veteran). Just like the Jewish apocalypticists, Chipanga used pseudonymity deliberately and avoided mentioning names of the living that he addressed. Unlike at the beginning of his song where he mentioned real names like Chaminuka, Nkomo, among others, later, he only used titles (chimbwido, mujibha and comrade). Once again, he hid the names of the real people he was addressing, and this enabled him to present his message uninterrupted.

Another characteristic of Jewish apocalypticism reflected in Chipanga music is symbolism. Like Jewish apocalyptic authors, for example, the author of the Book of Daniel who used symbols like animals to represent the ruling authorities of the day, Chipanga's apocalyptic music portrays the authorities in the same way. For instance, 
animals within the Zimbabwean society are used metaphorically to represent humans or to register grievances where direct communication is difficult (Tatira 2004). In typical apocalyptic fashion, Chipanga conceals the message with the use of numbers. The number ' 3 ' is prominent in the song. In his strategy, the number 3 represents, First, Second and Third Chimurenga. He connects the three to the land issue, hence, the title of his song, Ivhu redu nderipi? In the song Ivhu redu nderipi? he shows that the three revolutions were fought by the poor and for the poor to access land.

Chipanga also arranges his addressees in three sets of three. In the song Dafi (Frog) (2004), Chipanga criticized the government policy of land reform that gave way to the removal and murder of white farmers on their farms. His premise is that although Zimbabwe is for the blacks, whites also have a right to live there. For him, Zimbabwe was self-sufficient, probably because of the white farmers. Hence, to chase them or kill them would create problems of food shortage. To avoid a direct attack on the policy of the government, Chipanga uses common Shona beliefs about the relationship between a well and a frog. The Shona people believe that frogs are not to be killed if you find them in your well. If one would have a problem with the frogs, it is better to boil the water before drinking than to kill a frog. Frogs are believed to be guardians of wells; hence, if one kills frogs in a well, the well may dry up. In this euphemism, Chipanga criticizes the government for issuing policies that cause hunger because white farmers who were responsible for food security were being murdered. As in Jewish apocalypticism in which symbolism might also serve to safeguard the meaning of a text from being unravelled in cases that it might be unsafe to speak plainly, Chipanga's music served a similar purpose.

In the song Hove dzemugungwa (Fish from the sea) (2015), Chipanga uses sarcastic language. He argues that if the fish in the sea complains about the water being less what about the ones in the river. Thus, to him, if the wealthy ruling elite complain about how hard the economic, social, political life has become, then how much more would the commoners? This sarcastically means that the rich are the fish in the sea, and the poor are the fish in shallow rivers. Thus, the song indicts the rich, as they cannot complain of economic hardship because they are the ones in excess of all commodities.

Dualism is another characteristic of apocalypticism reflected in Chipanga's music. An analysis of Chipanga's apocalyptic music reflects this feature. According to Ndebele (2007), the genre of apocalyptic music is characterised with innuendos, double meanings or ghost names. Chipanga in the song, Zvimwe zvinoda mutorwa (Some issues need outsiders to assist) (2010), portrays the futility of inward-looking policies of the government (Chitofiri et al., 2017). Particular reference by Chipanga was to the land reform and another raft of indigenisation laws that followed. These policies drove foreigners away, resulting in the calamities. For Chipanga, if one wants milk and honey, cows and bees respectively are indispensable. Hence, if the government wants foreign currency, for example, then, foreigners should be indispensable too. Chipanga pursued this same theme later in the song Huchi (Honey) (2015). Chipanga sets the situation in a dualistic conflict where the words 'locals' and 'foreigners' are used to convey a message, and especially as both a gospel singer and sungura musician, he mentions God but also Satan. He depicts the government as Satan, therefore, it is clear that he appeals to dualism as a characteristic of apocalypticism. In his song Pharaoh, he refers to two experiences of Egypt and Canaan, represented by Moses and Pharaoh, though to him the Moses of 
Jewish Apocalyptic Features \& Zimbabwean Apocalyptic Music: Reflection on Hosiah Chipanga Music 9

Zimbabwe became the Pharaoh. Poverty, in this case, is Egypt and prosperity is Canaan. However, according to Chipanga, the impediment on the road to Canaan was Pharaoh who was unrelenting. Pharaoh continued to pursue Zimbabweans.

In the song Pharaoh, Chipanga avoids the direct attack by appealing to the wellknown biblical story of the Israelites. According to Chitofiri (2017), the song equates contemporary Zimbabwean experiences with those of the Israelites on their way from Egypt to Canaan with the reigning Egyptian Pharaoh's forces in pursuit. The same feature is reflected in Chipanga's song KwaMarange (2015). In the song, he tells God how difficult life has been in Marange as the soil is sandy, and it is a low rainfall region. Hence Chipanga tells God that "when you provided diamonds, we celebrated thinking that you had provided a solution to our problems". However, the deployment of soldiers and police and subsequent removal of the residents of Marange to pave the way for big diamond mining companies had become a source of bitterness. In the song, he portrays two settings - the side of goodness and the side of bitterness.

Furthermore, Chipanga (2012) continually makes use of symbolic language. In the song Murombo haana chake (A pauper owns nothing), Chipanga tries to show the nature of poverty and the aspect of discriminative social classes. He expresses this in the statement, Zvawati tarasa tonhongawo isu (We pick from what falls from your table). These show the ruling elite specialising in self-embezzlement at the expense of the poor. Thus, from these words, the poor are encouraged to recognise that the state in which they are is due to the way the rich grab everything. He further expresses his discontent in the statement, Vapfupi kudya zvirimuvhu pasi (The heritage of the short is what falls on the ground). This is an idiom that shows that the shorter are the poor in society and the taller are the rich, especially the elite. The rich have access to resources using their political muscles and nepotism to make economic gains.

Furthermore, in Chipanga's music, the idea of things getting better in the future is rendered in an eschatological tone through its promise of hope. Since Chipanga and his constituency, the poor of Zimbabwe, are powerless to confront the state openly, their only salvation is to long for another world to come; a world that is run differently from the current one. This is an embedded way of calling for a revolution to overthrow the oppressive Zimbabwean regime. Chipanga's description of the current problems in songs such as Kurongerana (Trapping each other), (Hapana dhiri (No deal) (2019), Zvaita nyika (State of the nation) (2019), and of the world to come, creates in his constituency zeal to fight for a better world. Such apocalyptic eschatological element is replete in Chipanga's other songs, Tumai Moses (Send Moses to us) (1996), Umambo Hwekudenga (Heavenly Kingdom) (2019) and Simba renyu ngariuye (Let your power be manifest) (2019). For Chipanga diseases, hunger, and all the problems faced in this world are evidence of the rule of the devil on the earth. He, therefore, calls for the immediate and quick intervention of God. God's rule is characterised by justice and righteousness, love and prosperity. Contrary to the narrative of Zimbabwean leaders that they are God-sent, Chipanga describes them as enemies of God.

Additionally, some of Chipanga's music speaks of past events, yet they critique the present. In this way, he avoids the quick association of his music with current events, thereby allowing the message to get to the people before being banned from public airing. Exhortation as another feature of Jewish apocalypticism is reflected also in Chipanga's music, for instance, in his song Gushungo (2006) in which he tried to praise Mugabe for 
the land reform program. His aim in this song was to get an opportunity to meet the President and share with him a message on good governance. It has been observed that apocalypse exhort its readers through encouragement to repent so as not to face coming judgement. Similarly, Chipanga's apocalyptic music encourages people to endure and fight for their freedom.

\section{Conclusion}

In conclusion, the article has investigated the elements of Jewish apocalypticism as reflected in the apocalyptic music of Hosiah Chipanga. Although not all the features of apocalypticism were analysed, the chief features such as revelation, symbolism, dualism, exhortations, pseudonymity, vaticinium ex eventu and eschatology were considered. As a background, the birth and characteristics of apocalypticism from Jewish circles were examined, and the chief characteristics were analysed in the light of Daniel, Revelation and non-canonical books. Then, the article considered the life of Chipanga as a seer and the context of Zimbabwean apocalyptic music. It was noted that unfulfilled liberation promises and continued oppression birthed apocalyptic music in Zimbabwe. It was concluded that Chipanga's apocalyptic music reflects apocalyptic features which in turn justify that his music is apocalyptic. It was also observed that as a Christian and selfproclaimed prophet, Chipanga's apocalyptic music reflects both biblical and social influences. From a comparative typological analysis theory and in terms of functionality, the Jewish apocalyptic features and their manifestation in Chipanga's music served to communicate with people when they were disillusioned. It has also been noted that like Jewish apocalyptic literature, Chipanga's apocalyptic music birthed the spirit of hope among Zimbabweans. Hence, Chipanga's songs highlighted in the article were those that could comparatively be analysed in relation to their functions in Zimbabwe.

\section{BIBLIOGRAPHY}

Baucham, R. 2008. The Jewish world around New the Testament.Tubingen: Mohr Siebeck.

Boadt, L. 1984. Reading the Old Testament: An introduction. Mahwah: Paulist Press. Buttrick, G. A. 1989. The Interpreters' Dictionary of the Bible. Nashville: Abingdon Press.

Chipanga, H. 1996. Tumai Moses. [Sound recording].

Chipanga, H. 2015. Hove demugungwa. [Sound recording].

Chipanga, H. 2019. Humambo hwekudenga. [Sound recording].

Chipanga, H. 2019. Simba renyu ngariuuye. [Sound recording].

Chipanga, H. 2019. Zvaita nyika. [Sound recording].

Chipanga, H. 2019. Kurongerana. [Art] (Record and tape promotion).

Chitofiri, K.2017. Fighting for justice and freedom through music: The case of Thomas Mapfumo, Hosiah Chipanga and Leonard Zhakata. South African Journal of African Languages, pp. 59-73.

Collins, J.1998. The apocalyptic imagination: Introduction to Jewish apocalyptic literature. Grand Rapids: Wm.B.Eerdmans Publishing Company. 
Jewish Apocalyptic Features \& Zimbabwean Apocalyptic Music: Reflection on Hosiah Chipanga Music 11

Collins, J. 2003. Introduction: Towards the morphology of a genre. Missoula: Missoula Scholars' Press.

Cook, S.L .995. Prophecy and apocalypticism: The postexilic social setting.

Minneapolis: Fortress Press.

Dunn, J.D.1977. Unity and diversity in the New Testament. London: SCM Press.

Hartman, L.F. 1978. The Anchor Bible: The Book of Daniel (Vol 23). New York: Doubleday and Company.

Helberg, J. 1994. Die boek Daniel: Skrifuitleg vir Bybelstudent enGemeente, N.G. Kerk-Uitgewers. Town: PMid.

Horsley, R., 2012. After Apocalypticism and Wisdom: Rethinking texts in context. Eugene: Cascade.

Koch, K. 1972. The rediscovery of apocalyptic. London: SCM Press.

Kummel, W.G.1990. Introduction to the New Testament. London: SCM Press.

Lawrence, W. 2005. Confronted boundaries in Wisdom and Apocalypticism. Society of Biblical Literature Symposium Volume 35.

Lucas, E.C. 2002. Apollos Old Testament Commentary. Leicester: Apollos.

Masau, P. 2013. Hosiah Chipanga on enigmatic lifestyle: The Herald.

Mazzaferri, F.D. 989. The genre of the book of Revelation from a source-critical perspective. New York: Walter de Gruyter.

Milinovich, T. 2011. The purpose and conflict of 'Vaticinum ex eventu' prophesy/apocalypse - [Online] Available at: http://www.pauletteLittera.com.

Murphy, F. 1996. Introduction to Apocalyptic Literature. Nashville: Abingdon Press.

Ndebele, Z. 2016. Freemouse. [Online] Available at: https://www.freemouse.org.

Nickelsburg, G.W.2003. Perspective: An ongoing dialogue of learning (Volume One). Leiden: Koninklijke Brill.

Sanders, E.P. 1972. 'The genre of Palestinian Jewish Apocalypses' in Apocalypticism in the Mediterranean world and the near east: Turbigen J.C.B.Mohr.

Smith, J.Z. 2011. Apocalypse against Empire: Theologies of resistance in early Judaism. Grand Rapids: William B Eerdmans Publishing Company.

Vries, S.J. 1995. From old Revelation to new: A tradition-historical and redactioncritical study of temporal transitions in prophetic predictions: Wm.Eerdmans Publishing Company. 